\title{
Jurisdiction of the United States Board of Tax Appeals Under the Revenue Act of 1926
}

\section{$\mathrm{T}$}

HE creation of the Board of Tax Appeals ${ }^{1}$ under the Revenue Act of $1924^{2}$ marked a distinct step forward in the administration of federal taxation. Prior to the enactment of the 1924 Act, the power of the Commissioner of Internal Revenue in the collection of taxes was well-nigh absolute. The Commissioner's determination that an additional tax was due was final, and was subject to review only by suit in court to recover the tax in dispute after its payment. The Commissioner was vested by statute with extraordinary powers ${ }^{3}$ to enforce collection of the tax by distraint proceedings. The Commissioner was authorized to assert and collect fraud and negligence penalties in the same manner without a jury trial or a hearing before an independent tribunal either executive or judicial in nature. ${ }^{4}$ The collection by the Commissioner of additional tax, penalty, or interest could not be enjoined. ${ }^{5}$ As will later be pointed out, this latter rule has been modified by the Revenue Act

1 For an exhaustive and authoritative treatise on the organization, powers and functions of the Board under both the 1924 and 1926 Revenue Acts, see Charles D. Hamel, United States Board of Tax Appeals-Practice and Evidence. See also Robert H. Montgomery, Income Tax Procedure, 1927; Holmes and Brewster, Practice and Procedure-Board of Tax Appeals; George E. Holmes, Federal Taxes (6th ed.). The two latter-named authorities deal with the Board under the 1924 Act, only. An edition of Holmes and Brewster in which the functions of the Board under the 1926 Act are considered has been announced for early publication.

2 Act of June 2, 1924, $\$ 900$. The jurisdiction of the Board is defined in $\S \S 274,279,280,308,312$ and 316 of that Act.

3 U. S. Rev. Stats. $\S \S 3187-3195$. The amount of the tax assessed became a lien on the taxpayer's property; U. S. Rev. Stats. \& 3186. Both real and personal property could be seized and sold for unpaid taxes. U. S. Rev. Stats. sิ 3196-3208.

4 U. S. Rev. Stats. $\S 3176$, Revenue Act of October 3, 1917, § 1004, Acts of Feb. 23, 1919, and Nov. 23, 1921, \$ $250(\mathrm{~b})$. A penalty of 100 per cent of the tax evaded was imposed by the Act of Oct. 3, 1917, while a penalty of 50 per cent was imposed by U. S. Rev. Stats. $\$ 3176$ and subsequent Revenue Acts.

5 § 3224 U. S. Rev. Stats. provides: "No suit for the purpose of restraining the assessment or collection of any tax shall be maintained in any court." See Dodge v. Osborn (1915) 240 U. S. 118, 60 L. Ed. 557, 36 Sup. Ct. Rep. 275. Certain exceptions which the courts originally read into the statute have since been abandoned. Distrained property can not be replevied. U. S. Rev. Stats. \$ 954. 
of 1926..$^{\circ}$ The harsh rule of payment first and litigation afterward prevailed. ${ }^{7}$

The importance of the powers vested in the Commissioner was not realized until the adoption of the Sixteenth Amendment to the Constitution and until the exigencies of the World War required a tremendous increase in revenues. Internal revenue collections increasei from 41 per cent of all ordinary receipts in 1909 to 89 per cent in 1918. In 1920, the record year, internal revenue receipts were $\$ 5,399,149,245.06$. From 1913 to 1924, individual and corporation tax returns filed, increased from 674,507 to $7,714,184$. The number of employees of the Bureau of Internal Revenue, in Washington and in the field, increased from 4,929 in 1917 to 17,687 in 1922.8 It was inevitable that, with such an increase in the returns filed the amounts of tax involved, mistakes in the administration and application of the tax laws would occur. The combination of judge, prosecutor and party litigant has never been satisfactory.

It was to provide an independent reviewing tribunal for the Burea1 of Internal Revenue that the Board of Tax Appeals was created by the Revenue Act of 1924. The Board is designated in both the 1924 and 1926 Acts as "an independent agency in the executive branch of the government." 9 Although the jurisdiction of the Board under the 1924 Act was more limited than under the 1926 Act, it has functioned to the satisfaction of both the taxpayers and the Bureau of Internal Revenue. On March 1, 1926, just subsequent to the enactment of the 1926 Act, ${ }^{10} 12,347$ appeals involving an average deficiency of $\$ 15,894.93$ had been filed with the Board. More than one-half of these appeals had either been finally disposed of or submitted to the Board for decision, after hearing, by March 1, 1926.11 On January 3, 1927, the number of appeals filed totaled

${ }^{6}$ Under $\$ \S 274(\mathrm{a})$ and 308(a) of the 1926 Act, the Commissioner is required to notify the taxpayer of his determination by registered letter and the taxjlayer is authorized to appeal to the Board from this determination. Until sich notice has been mailed, for a period of sixty days after said mailing, and, if, pursuant thereto, an appeal is filed with the Board, until the decision of the Board becomes final, the assessment or collection of the tax proposed except in case of jeopardy is prohibited.

7 For an excellent discussion of the conditions responsible for the creation of the Board, see Albert L. Hopkins, The United States Board of Tax Appeals, 12 American Bar Association Journal, 466.

${ }^{8}$ For an interesting discussion of the development of the Bureau of Internal Revenue since the adoption of the Sixteenth Amendment, March 3, 1913, see Hamel, United States Board of Tax Appeals-Practice and Evidence, tp. 1-11.

9 \$ $900(\mathrm{k}), 1924$ Act; $\$ 900,1926$ Act.

10 A.pproved Feb. 26, 1926.

11 See Hamel, United States Board of Tax Appeals-Practice and Evidence, p. 17. 
22,298. The importance of the Board in the administration of the federal revenue laws is established.

Under the Revenue Act of 1926, the salutary rule permitting litigation before payment established by the 1924 Act was continued in full force and effect; in addition, the powers and jurisdiction of the Board were materially extended. Under the 1924 Act the Board had no jurisdiction to order refunds, even though a deficiency had been asserted for the year in question and the appeal was properly before the Board. ${ }^{12}$ Under the 1926 Act, in a case properly before the Board, if it is determined that the tax has been overpaid a refund may be ordered. ${ }^{13}$ Under the 1924 Act, payment of the tax prior to the decision of the Board ousted the Board of all jurisdiction. ${ }^{14}$ Under the 1926 Act, subject to certain modifications which will be noted later, payment has no bearing on the jurisdiction of the Board. ${ }^{15}$ Under the 1924 Act, the Board's findings of fact in any particular case were merely prima facie evidence in any subsequent suit in court. ${ }^{18}$ Under the 1926 Act, once an appeal is filed with the Board, both the taxpayer and the Commissioner must pursue their remedy as provided by that act, which requires a petition for review of the Board's decision addressed by the defeated party either to a Circuit Court of Appeals or the Court of Appeals of the District of Columbia. ${ }^{17}$ No independent proceeding in court may later be brought by either party.18

It may naturally be expected, therefore, that the bulk of the tax litigation in the future will be carried on before the Board. Few taxpayers will prefer to pay the tax and later sue in court for its recovery. Although interest on overpayments, representing theoretical compensation for wrongful payment, is allowed, it is often entirely inadequate. The Board, though termed in the statute an "agency in the executive branch of the Government", in all but name is a court limited in jurisdiction to the consideration of litigation involving federal taxes. ${ }^{19}$ Its character and functions while

12 Appeal of Everett Knitting Works (1924) 1 B. T. A. 5; Appeal of J. Victor Baron (1924) 1 B. T. A. 15.

$13 \S \$ 284$ (e) and 319 (c), 1926 Act.

14 Appeal of The Northwestern Mut. Life Ins. Co. (1925) I B. T. A. 767. $10 \$ \$ 274,279,283,308,312$ and 318,1926 Act.

$10 \$ 900(\mathrm{~g}), 1924$ Act.

$17 \$ 1001,1926$ Act.

$18 \$ \& 284$ (d) and $319(\mathrm{a}), 1926$ Act. The taxpayer is always permitted to pay the tax without appealing to the Board and to sue in a United States District Court for its recovery.

${ }_{19}$ See Report of Senate Finance Cómmittee (1926 Act) p. 35. In the Appeal of Edward I. Schneidenhelm Co. (1925) 1 B. T. A. 864, the Board said: ". . . the requirements of the section [900,1924 Act] vest this Board 
judicial in nature under the 1924 Act are even more clearly so under the 19.26 Act.

The jurisdiction of the Board under the 1924 and 1926 Acts is not general but limited. ${ }^{20}$ It is a familiar rule of law that forbids the extension of the jurisdiction of any tribunal beyond the strict confines of the statute under which it was created. In general, the Board under both acts has jurisdiction only when a deficiency in tax has been asserted by the Commissioner. The principal, if not the only, exception to this rule is in the case of transferees under sections 280 and 316 of the Revenue Act of 1926 . Under both the $1924^{21}$ and $1926^{22}$ Acts, the jurisdiction of the Board is limited to income, war-profits, excess-profits, estate and gift taxes. ${ }^{23}$ While the va:ious Revenue Acts have imposed a great variety of taxes, ${ }^{24}$ the five types just enumerated have been the largest revenue produc$\mathrm{ers}^{25}$ and of the greatest general interest because of the amount of tax and complexity of the problems involved. The jurisdiction of the Bcard is also limited as to the years involved. Only income, excess-profits, war-profits, estate and gift taxes imposed by the Revenue Acts of 1916,1917, 1918, 1921 and 1924 may be reviewed by the Board under the provisions of the 1924 Act." ${ }^{28}$ Under the $1926 \mathrm{Act}^{27}$ the same taxes imposed by the same prior Acts, with which are included those imposed by the 1924 Act and those imposed by the 1926 Act, may be considered. The doubt which at first existed under the 1924 Act as to the jurisdiction of the Board with regard

with the main attributes of a court and make.it a tribunal, entitled to respect and charged with great responsibilities."

20 " j.t is a tribunal of limited jurisdiction and its powers are strictly confined to those affirmatively vested in it by the Act under which it was created." Appeal of Clois L. Greene (1925) 2 B. T. A. 148.

211924 Act, $\$ \$ 900,274,279,280,308,312$ and 316.

221926 Act, $\$ \S 904,274,279-284,308,312-319$.

23 Appeal of The Aldme Club (1925) 1 B. T. A. 710. Excess-profits taxes were imposed from 1917 to 1921, inclusive; war-profits taxes during 1918 only; gift taxes during 1924 and 1925; and estate and income taxes by all Acts from 1916 to the present.

24 For example, the 1918 Act imposed the following miscellaneous taxes: tax on transportation and other facilities; tax on insurance; tax on beverages, cigars and tobacco; tax on admissions and dues; various excise taxes; various special taxes; stamp taxes; and tax on employment of child labor. A substantial portion of these miscellaneous taxes has been retained under recent Acts, but in no case is the Board permitted to review the Commissioner's determination with regard thereto.

25 The excess-profits tax produced more revenue than any other tax ever imposed. Although no excess or war-profits taxes have been imposed since 1921, many cases involving these taxes remain undisposed of even at the present, as administrative problems always survive the repeal of a tax statute.

$26 \$ 280$ and 316,1924 Act. Appeal of Gutterman Strattss Co. (1924)

1 B. T. A. 243.

$27 \S \S 283$ and 318, 1926 Act. 
to taxes imposed by prior Acts has since been removed by decisions of the Board, ${ }^{28}$ together with certain express provisions of the 1926 Act. ${ }^{29}$

The Board is a tribunal possessing the attributes of a court and will take jurisdiction only of actually litigated tax problems. It has neither the time nor power under either the 1924 or 1926 Acts to consider moot questions. ${ }^{30}$ The Board will not, under either Act, review matters of general Bureau administration..$^{31}$ The Board, however, is not limited to a consideration of those matters and issues raised before the Bureau. The duty of the Board under both the 1924 and 1926 Acts is to determine the deficiency, if any, due from the taxpayer. Any natters properly pleaded before the Board may be presented. ${ }^{32}$ As may properly be expected, jurisdiction may not be conferred on the Board either by estoppel or consent of the parties. $^{33}$

\section{Assessments}

The question of whether or not the deficiency proposed by the Commissioner had been assessed was of prime importance under the 1924 Act and is still of some iniportance under the 1926 Act in determining whether or not the Board has jurisdiction in a particular case. $^{34}$ Before discussing the jurisdiction of the Board in specific cases, it will be necessary, therefore, to consider briefly the meaning, nature and effect of an assessnient. In general, the assessment of the tax shown on the original return occurs when the return is filed with the Collector of Internal Revenue. The assessnient of an additional tax proposed, occurs when a roll containing the name and address of the taxpayer, the taxable period involved, and the nature and amount of the tax proposed, is signed by the Comimissioner or

28 Appeal of Gutterman Strauss Co., supra, n. 26.

29 \& 283, 1926 Act.

30 Appeal of General Equipment Co. (1925) 2 B. T. A. 804. In this case the deficiency asserted was income tax only. The taxpayer alleged error in the Commissioner's determination of invested capital. The Board refused to consider the point because in that case the determination of invested capital had no relation to the amount of income tax due. See also Appeal of Walcott Lathe Co. (1925) 2 B. T. A. 1231.

31 The Board has refused to decide whether the Commissioner should accept amended returns. Appeal of Junkel \& Co., Inc. (1925) 3 B. T. A. 133.

32 Appeal of Gutterman Strauss Co., supra, n. 26.

38 Appeal of Rateau Battu Smoot Co. (1925) 1 B. T. A. 354. Appeal of Alfred C. Ruby (1925) 2 B. T. A. 377.

$34 \S \S 274,279,280,308,312$ and 316,1924 Act; $\$ \S 274,279,283,308,312$ and 318,1926 Act. 
his dily authorized representative. An additional tax may not be collected by distraint until it has been assessed. An assessment, however, is not a prerequisite to collection of the tax by suit in court. $^{35}$ No lien for taxes attaches to the taxpayer's property until an assiessment has been made. ${ }^{36}$ The introduction in evidence of the assessment list in regular form showing the assessment of the tax in dispute constitutes a prima facie case for the United States in a suit to recover the tax..$^{37}$ The date of assessment becomes important in determining whether the statute of limitations will bar collection. ${ }^{38}$ The date of assessment determines, in certain cases, the period during which interest on deficiencies accrues against the taxpayer and also marks the period for which interest accrues to the taxpayer in case of refund because of overpayment. ${ }^{39}$

Under the Revenue Acts of 1924 and 1926 specific provision is made for jeopardy assessments as distinguished from assessments in the regular course after a due consideration of all the issues involvecl. ${ }^{40}$ Such jeopardy assessments were not recognized by any Revenue Act prior to the 1924 Act, but were made as a matter of Bureau procedure. Under the 1924 Act, such jeopardy assessments might be made at any time, even though an appeal had been filed with the Board, provided the assessment was made before the final decision of the Board. ${ }^{11}$ Under the 1926 Act, such assessments may be made at any time before the decision of the Board becomes final. Under both acts, the jeopardy assessment might be made in an amount either greater or less than that shown in the deficiency letter,

35 278, 1924 and 1926 Acts; King v. United States (1887) 99 U. S. 229, 25 L. Ed. 373; United States v. Ayer, et al. (C.C.A.,1st C.,1926) 12 F. (2d) 194. Under the 1924 Act, if the decision of the Board was adverse to the Commissioner the latter was precluded from making an assessment but was authorized to institute suit to recover the tax alleged to be due; \$\& 274(b) and 308(b), 1924 Act. Under the 1926 Act, the Commissioner is required to petition a Circuit Court of Appeals or the Court of Appeals of the Disitrict of Columbia for a review of the Board's decision.

86 Jnited States v. Pacific Railroad et al. (C.C.E.D.Mo.,1880) 1 Fed. 97. 28.

37 Western Express Co. v. United States (C.C.A.,8th C.,1905) 141 Fed.

$38 \$ \$ 250$ (d) and 1322, 1921 Act; $\$ \$ 277,278,310,311$ and 1009, 1924 Act ; $\$ 3277,278,310,311$ and 1109,1926 Act.

39 \& 250 and 1324, 1921 Act; $\$ \$ 274,276,279,308,312$ and 1019, 1924 Act; $\$ \$ 274,276,279,283,308,312$ and 1116, 1926 Act. See also Girard Trust Co., et al. v. United States (1926) 270 U. S. 163, 70 L. Ed., Adv. Ops. 350, 46 Sup. Ct. Rep. 229.

$40 \& \$ 274(\mathrm{~d}), 279,308(\mathrm{~d})$ and 312, 1924 Act; $\$ \$ 279$ and 312, 1926 Act. The laiaguage in both Acts is practically identical: "If the Commissioner believes that the assessment or collection of a deficiency wil be jeopardized by delay, he shall immediately assess such deficiency . . ."

$41 \S \$ 274$ (d) and $308(d), 1924$ Act. 
except that under the 1926 Act, after the decision of the Board but before the decision becomes final, the assessment can not exceed the deficiency as determined by the Board. ${ }^{42}$ The collection of the tax may be deemed to be in jeopardy because of insolvency, bankruptcy, dissolution if a corporation, or the running of the statute of limitations on assessment and collection. The determination that jeopardy exists is solely within the discretion of the Commissioner and his reasons for making such an assessment are not subject to review. ${ }^{43}$ Prior to the enactment of the Revenue Act of 1921, which provided for an appeal to and hearing before the Bureau, where a deficiency was asserted, ${ }^{44}$ it was the practice of the Bureau to immediately assess any deficiency proposed by the examining revenue agent prior to a determination of the issues, on their merits, and even though no jeopardy existed. In such cases, the Bureau ordinarily accepted a claim in abatement of the amount assessed pending a final determination of the questions involved. Even subsequent to the 1921 Act, in certain cases assessments were made which neither represented the final determination of the Commissioner nor were impelled by jeopardy. Under the 1924 Act, an assessment was contemplated only after a final determination by the Commissioner, which assumed the right of an appeal to the Board, or in case of jeopardy. It was specifically provided that no claim in abatement except of a jeopardy assessment would be entertained..5 The same conditions prevail under the 1926 Act except that all claims in abatement were abolished and the collection of the tax assessed because of jeopardy, can be stayed by the filing of a bond. ${ }^{46}$ The importance of the assessment as reflecting the final determination of the Commissioner, upon which the jurisdiction of the Board depends, will be pointed out later.

\section{Necessity for a Final Determination}

In general, the Board has jurisdiction in all cases where the Commissioner proposes to collect a tax in excess of that shown to

$42 \$ \$ 279(\mathrm{c}),(\mathrm{e})$ and $312(\mathrm{c}),(\mathrm{e}), 1924$ Act. The decision of the Board under the 1926 Act becomes final when the period allowed for appeal therefrom has expired or the reviewing court has finally passed thereon. $\$ 1005$, 1926 Act.

${ }_{13}$ Appeal of Cal. Assoc. Raism Co. (1925) 1 B. T. A. 1251; Report of Senate Finance Committee to accompany H. R. I. (1926 Act) D. 27.

$\$ 4 \$ 250$ (d), 1921 Act.

$15 \$ \$ 279$ (d) and 312(d), 1924 Act.

$46 \$ 279$ and 312,1926 Act. 
be due on the original return. In the 1924 Act, with regard to taxes imposed by that Act (for 1924 and subsequent years), the Board was given jurisdiction in all cases where "the Commissioner determines that there is a deficiency."47 With regard to taxes imposed by prior acts, jurisdiction was held to be conferred on the Board, "If after the enactment of this Act [1924], the Commissioner determines that any assessment should be made"18 of any tax imposed by such prior Act. Under the 1924 Act, the right of appeal to the Board with regard to taxes imposed by prior acts was not specifically granted, the statute providing ${ }^{49}$ only that such taxes should "be assessed" and "collected in the same manner . . . as in the case of taxes imposed by" the 1924 Act. The Board in an early case ${ }^{50}$ held that the language just quoted conferred jurisdiction where deficiencies were. proposed after the passage of the 1924 Act with regard to taxes imposed by prior acts. The provisions of the 1926 Act ${ }^{01}$ conferred jurisdiction on the Board with regard to deficiencies in taxes imposed by that act in all cases "where the commissioner determines that there is a deficiency", the language being identical with that vsed in the 1924 Act. With regard to taxes imposed by prior acts, the 1926 Act confers jurisdiction in language similar to that used by the 1924 Act. There are provisions in the new act, however, which remove any doubt that may have existed as to the jurisdiction of the Board with regard to such prior years. ${ }^{52}$ In all cases the determination from which the appeal is taken must have occurred after the enactment of the act in question. ${ }^{53}$

From the language of the sections of the 1924 and 1926 Acts already quoted, defining the jurisdiction of the Board, it is apparent that whether it be a tax imposed by the current Revenue Act or any prior Revenue Act, there must first be a determination by the Commissioner, which determination must be final. If the taxes in question are those imposed by either the 1924 or the 1926 Acts, the determination must be that a deficiency exists. If the taxes are imposed by any prior act, which in the case of the 1926 Act includes the 1924 Act, there must be a determination that any assessessment should be made. The difference in the language employed is so marked that

$47 \$ 274(\mathrm{a})$ and $308(\mathrm{a}), 1924$ Act.

48 is 280 and 316,1924 Act.

40 Supra, n. 48.

so Appeal of Gutterman Strauss Co., supra, n. 26.

51 \& $\$ 274$ and 308, 1926 Act.

52 is 283 and 318, 1926 Act.

53 After June 2, 1924, if the 1924 Act is involved; and after Feb. 26, 1926, if the 1.926 Act is involved. 
it would at first appear that the Board had no jurisdiction of any tax imposed by any prior acts, if the assessment whether jeopardy or not, was made prior to June 2, 1924, or February 26, 1926, in the case of the 1926 Act. A jeopardy assessment, however, by its very name connotes an absence of a determination on the merits of the issues involved. The question of the jurisdiction of the Board in case of a jeopardy assessment after the enactment of the 1924 Act can not arise as jurisdiction in such cases is expressly conferred upon the Board after the Commissioner has finally passed on the merits of the case. 54 Under the 1926 Act, the Commissioner is required to issue, within sixty days after the jeopardy assessment, a sixty-day letter giving the taxpayer the right to appeal to the Board, provided a bond to stay collection has been filed.55 With regard to taxes imposed by the 1924 and 1926 Acts, therefore, no question as to jurisdiction can arise when the jeopardy assessment was made after the enactinent of those acts. In view of these specific provisions conferring jurisdiction where the jeopardy assessment was made after the enactment of the 1924 and 1926 Acts, it is apparent that a jeopardy assessment made prior to the enactment of those acts was not intended to preclude appeal. With the exception of jeopardy assessments made after the enactment of the 1926 Act, the jurisdictional prerequisite is a final determination by the Commissioner, a question of fact. The Board has never hesitated to take jurisdiction in cases where the taxes involved were the subject of jeopardy assessment prior to June 2, 1924, provided the final determination of the Commissioner occurred subsequent to that date.

A more difficult question arose under the 1924 Act where an ordinary assessment had been made with regard to a tax imposed by prior Acts, either before the enactment of the 1924 Act or more than sixty days prior to the filing of the appeal. This problem could not arise with regard to a tax imposed by the 1924 Act because no ordinary assessment was authorized except after a final determination, which carried with it the right of appeal to the Board..$^{58}$ The same is true with regard to taxes imposed by the 1926 Act. ${ }^{57}$ While the general problem herein involved has become largely academic because of the express provisions of the 1926 Act, $^{58}$ it is important as indicating the nature of a final determination.

$54 \S \$ 279$ and 312, 1924 Act.

$55 \$ 279$ and 312 , 1926 Act. In this case alone the Board is given jurisdiction even though no final determination has been made by the Commissioner. $56 \$ 279$ and 312, 1924 Act.

$57 \$ \$ 279$ and 312,1926 Act.

os $\$ \$ 283$ and 318,1926 Act. 
With regard to such assessments made prior to June 2, 1924, of taxes imposed by prior acts, the Commissioner early contended before the Board in the Appeal of Joseph Garneau Company, Incorporated, ${ }^{58}$ that an ordinary assessment was per se a final determination and must occur after June 2, 1924, or within sixty days from the date of the filing of the appeal.

In the Garneau case, supra, the Commissioner, after a hearing, had assessed on May 27, 1924, the additional taxes proposed. The assessment in question was not a jeopardy assessment. The Revenue Act of 1924 was approved June 2, 1924, and by its express provisions the Board had no jurisdiction in any case where the Commissioner's final determination was made prior to June 2, $1924 .{ }^{\circ 0}$ The deficiency in question. was first proposed in December, 1923. The Bureau had denied the taxpayer's protests on April 2, 1924, and subsequently on April 29 and May 8 denied the taxpayer's requests for a reconsideration. Requests were again made for a reconsideration on May 10 and May 14. On May 27, 1924, the tax was assessed in the regular course of business. On July 17, 1924, the Commissioner advised the taxpayer by letter that its requests for reconsideration had been given "very careful consideration and the Bureau finds it necessary to sustain its previous decision." The taxpayer then appealed to the Board from this letter on August 17, 1924. The Commissioner moved to dismiss the appeal on the ground that the final determination occurred May 27, 1924, the date of assessment, and that in any event with regard to taxes imposed by prior acts there must be a determination after June 2, 1924, that an assessment should be made. The motion to dismiss was denied. ${ }^{61}$ This decision stands squarely for the proposition that an assessment, whether jeopardy or ordinary, is not per se a final determination. The converse of this rule, that the final determination is the determinative factor in deciding jurisdiction, is also established by this case.

While the principle laid down by the Board in the Garneau case appears sound, there is serious question as to the correctness of its

59 (192̀) 1 B. T. A. 75.

60 s 280 and 316,1924 Act. Both sections provide: "If after the enactment of this Act, the Commissioner determines that any assessment should be made .."

61 The Board said in part in its opinion, p. 78: "Our attention is directed by the Commissioner to the importance of the fact that assessment of the tax was made on May 27, 1924, and this was a determination prior to June 2, 1924. The statute clearly differentiates the several steps of determination, assessment, and collection, and requires the Commissioner to notify the taxpayer of his determination as the very foundation of his appeal." 
conclusion in that particular case. Even though the date of assessment was not determinative, it would seem that the final determination had actually occurred prior to June 2, 1924, and even prior to May 27, 1924, the date of assessment, and that the Board was therefore without jurisdiction. The Commissioner's letter of July 17, 1924, was in reality merely an explanatory letter subsequent to the final determination. The Commissioner should not be penalized for the courtesy of a reply to the taxpayer, and the Board has so held in later cases. ${ }^{62}$ The Commissioner not only refused to acquiesce in this decision, but refused to file an answer to the taxpayer's petition and instructed the Collector to enforce collection. A bill to enjoin collection was filed in the United States District Court, New York, by the taxpayer and was dismissed under section 3224 of the Revised Statutes. ${ }^{63}$ The principle estabhshed by the Garneau case that an ordinary assessment is not per se a final determination has been repeatedly affirmed by the Board. ${ }^{64}$ It thus appears that the Board has held that the provisions of the 1924 Act, "that there is a deficiency",", with regard to taxes imposed by that act, and "that any assessment should be made", 66 dealing with taxes imposed by prior acts, are coextensive, and that in either case all that is necessary for the jurisdiction of the Board is a final determination by the Commissioner after June 2, 1924. This conclusion is true, despite the fact, as will be pointed out later, that "deficiency" as defined in both the 1924 and 1926 Acts $^{87}$ does not of itself include additions to the tax by way of penalties or interest, while "any assessment" will clearly include any additions to the tax. The language in the 1926 Act in the above connection being identical with that in the 1924 Act, the decisions of the Board in this connection will govern.

The $1926 \mathrm{Act}^{\mathrm{B8}}$ removed any doubt as to the jurisdiction of the Board in cases where the tax was assessed prior to June 2, 1924, or February 26, 1926, regardless of the nature of the assessment. If

62 Appeal of Robert D. Gould (1925) 1 B. T. A. 846.

83 Joseph Garneau Co., Inc., v. Bowers (D.C.,S.D.N.Y.,1925) \& F. (2d) 378, decided July 16,1925 . In a somewhat similar case injunctive relief was granted the taxpayer; Lafayette Worsted Co. v. Paige (D.C.,R.T.,1925) 6 F. (2d) 399, decided June 24, 1925 . It was because of the uncertainty in such cases that $\S 3224$, U. S. Rev. Stats. was expressly stated in the 1926 Act, $\$ \S 274(a)$ and $308(a)$, to be inapplicable pending an appeal to the Board. 64 Appeal of Terminal Wine Co. (1925) 1 B. T. A. 697; Appeal of The Buffalo Slag Co. (1925) 1 B. T. A. 749.

$65 \S \S 274$ and 308,1924 Act.

$66 \$ \S 280$ and 316,1924 Act.

o7 $\$ 273$ and 307,1924 and 1926 Acts.

$88 \S \S 283$ and 318,1926 Act. 
the final determination occurred after February 26, 1926, the Board has jurisdiction even though the tax was assessed prior to June 3, 1924.99 If the final determination occurred prior to February 26, 1926, but after June 2, 1924, the Board has jurisdiction even though the assessment may have been made before June 3, 1924. ${ }^{70}$ The decisions of the Board in the Garneau case and companion cases may he of immediate practical importance under the 1926 Act despite the express provisions of that statute. Under both the 1924 and 1926 Acts it was intended that except in the case of jeopardy there should be no assessment until after a final determination, with the right of an appeal to the Board. There may be cases, however, where an assessment was made after the enactment of the 1924 and 1926 Acts, which assessment neither resulted from jeopardy nor represented the final determination of the Commissioner. In such cases the principle enunciated in the Garneau case is applicable and the taxpayer is entitled to appeal to the Board when the final determination actually occurs.

\section{What Constitutes the Final Determination}

It thus clearly appears, both from the Garneau case and from the provisions of the 1926 Act, $^{71}$ that the first requisite for the

jurisdiction of the Board is a final determination by the Commissioner. What constitutes a final determination is a question of fact. The clate this final determination occurs is of great importance, as under both the 1924 and 1926 Acts $^{72}$ the taxpayer's appeal must be filed with the Board within sixty days ${ }^{73}$ of the date the notice of such determination is mailed to the taxpayer. The Commissioner is required to notify the taxpayer of his determination by registered letter and the statutory period begins to run from the date of the mailing of such notice. ${ }^{74}$ The usual letter ${ }^{75}$ employed by the Com-

69 is 283(a), (e) and 318(a), (d), 1926 Act.

70 is 283(b), (f) and 318(b), (e), 1926 Act.

$71 \$ 283$ and 318, 1926 Act.

72 274 and 308, 1924 and 1926 Acts.

73 Jnder the 1924 Act, all Sundays were included. Under the 1924 Act, Sunday if the sixtieth day is excluded.

74 Appeal of Sam Satovsky (1924) 1 B. T. A. 22 . Under the 1924 Act, if the Commissioner failed to give the taxpayer a letter from which an appeal could be taken and proceeded to collect the tax, the taxpayer apparently had no remedy because of the provisions of $\$ 3224, U$. S. Rev. Stats. See n. 62, supra, however. Under the 1926 Act, it is specifically provided that assessment and collection may be enjoined until such a notification of final deterinination has been mailed to the taxpayer.

75 Known as the NP 2 letter. 
missioner specifically informs the taxpayer that this is the Commissioner's final determination and advises the taxpayer of the right to appeal to the Board. In some cases, however, it does not so clearly appear that the notice in question represents the Commissioner's final determination and it then devolves upon the taxpayer and his counsel to determine what constitutes such determination.

It is clear that the ordinary thirty-day letters received from the local Internal Revenue Agent in charge or from the Bureau ${ }^{76}$ do not represent determinations by the Commissioner as contemplated by the statute, and the Board has so held. ${ }^{77}$ Such communications precede the final determination. There may be cases where the communication appealed from is subsequent to the final determination. Explanatory letters or letters from the Commissioner acknowledging receipt of communications from the taxpayer do not constitute determinations conferring the right of appeal to the Board.78 The practice has grown up for the Commissioner to issue so-called sixtyday letters to prevent the running of the statute of limitations. Such letters do no really represent final determinations, but for administrative reasons the Board has never hesitated to take jurisdiction. This practice on the part of the Commissioner and the Board is probably justifiable as jeopardy assessments are onerous, and, under the 1924 Act, if the taxpayer was unable to give bond, the Board had no jurisdiction. ${ }^{79}$ Jurisdiction can not be conferred on the Board by a letter which purports to be a notice of final determination but in fact is not. ${ }^{80}$ In case of doubt as to whether a communication from the Bureau constitutes a final determination, an appeal should be filed. In such cases, even though the appeal were later dismissed, the taxpayer should not be liable to the penalty for frivolous appeals provided for by the 1926 Act. $^{81}$

In a strict sense, it would appear that regardless of statutory provisions, there could be but one final determination for each taxable period. Under the 1924 Act, however, there was nothing to

70 The thirty-day letter from the Bureau in Washington is known as the NP 1 letter.

77 Appeal of Fidelity Insurance Agency (1924) 1 B. T. A. 86.

78 Appeal of Terminal Wine Co., supra, n. 63.

79 Appeal of Cal. Assoc. Raisin Co., supra, n. 43.

80 Appeal of Mohawk Glove Corp. (1925) 2 B. T. A. 1247; Appeal of Rateau Battu Smoot Co., supra, n. 33. In this latter case, the letter appealed from specifically stated that the taxpayer had sixty days within which to perfect an appeal to the Board. Although the appeal was filed within sixty days from the date of this letter, the Board refused to take jurisdiction. In this case the final determination in fact preceded the letter appealed from.

$81 \S 911,1926$ Act. 
prevent the Commissioner from reopening a case within the statute of limitations and making any number of final determinations desired. $^{52}$ If the case had been closed under section 1006 of the 1924 Act, both parties were of course bound by the agreenient. ${ }^{83}$ Under the 1926 Act, $^{84}$ however, the Commissioner is specifically preciuded, except in case of fraud, from making more than one determination of a deficiency in respect of the same taxable year. By reference this limitation is extended to taxes inposed by prior acts. $^{35}$ In all cases, of course, this inhibition applies only where the determination is made after February 26, 1926.

\section{Deficiency Defined}

A.s has been pointed out, the determination from which the appeal may be taken is stated to be "that there is a deficiency"so where taxes imposed by the 1924 and 1926 Acts are in issue, and that "any assesisment should be made"87 where taxes imposed by prior acts are involved. Both statutes define "deficiency"ss in substantially the same: language as the amount by which the tax actually due exceeds the amount shown on the return; or, if no amount was shown on the return or no return was filed, the amount actually due. A deficiency as such does not include penalties, interest or other additions to the tax, but both the 1924 and 1926 Acts specifically provide that penalties, interest and other additions to the tax shall be assessed, collected and paid in the same manner as a deficiency in tax. ${ }^{89}$ Since determinations concerning penalties, interest and other additions to the tax can be made only in the same manner as determinations of deficiencies, an appeal to the Board from such determinations is necessarily authorized. The Commissioner has never contended that the Board was without jurisdiction to review determinations concerning interest.

82 Appeal of Samuel E. A. Stern, et al. (1925) 2 B. T. A. 102.

83 Lone Star Brewing Assoc. v. United States (1925) $61 \mathrm{Ct} . \mathrm{Cl} .118$.

$84 \$ \S 274(f)$ and $308(f), 1926$ Act. Under the wording of the statute, it may be contended that this limitation applies only where a notice has been mailed and an appeal has actually been filed with the Board. If a notice has been mailed but no appeal filed, it would appear that an additional determination might be made.

$85 \& \& 283$ and 318,1926 Act.

$86 \$ 274$ and 308,1924 and 1926 Acts.

$87 \$ \$ 280$ and 316, 1924 Act; $\$ 283$ and 318, 1926 Act.

$88 \$ 273$ and 307,1924 and 1926 Acts. The 1926 Act specifically confines the definition to deficiencies in case of taxes imposed by the 1926 Act; the 1924 Act simply states: "As used in this title."

$89 \$ \S 274(\mathrm{f}), 275(\mathrm{a}), 308(\mathrm{e}), 308(\mathrm{~g})$ and $309(\mathrm{~b}), 1924$ Act; $\S \S 274(\mathrm{i})$ (j), $275(\mathrm{a}), 276^{\prime}(\mathrm{b}), 308(\mathrm{f})$ and $308(\mathrm{~h}), 1926$ Act. 
It was early contended, however, that the assertion of fraud or negligence penalties was not subject to review by the Board. This contention was based on the two-fold proposition that a penalty was not a part of the deficiency and that the determination that a penalty should be asserted was. solely within the discretion of the Commissioner. The Board overruled the Commissioner on both points. ${ }^{90}$ The Board's decision has been approved by the provisions of the 1926 Act. ${ }^{91}$

A similar question does not arise with regard to taxes imposed by prior acts as the determination in such cases is that "any assessment should be made". In both the. $1924^{92}$ and $1926^{93}$ Acts, any assessment is specifically defined as including interest, penalty and other additions to the tax. The jurisdiction of the Board in such cases is clear. It appears, therefore, both from the decisions of the Board and the language of both the 1924 and 1926 Acts, that the scope of the determination "that there is a deficiency" is coextensive with the scope of the determination that "any assessment should be made".

Some difficult problems may arise in the determination of what constitutes a deficiency. All that is said in this connection will apply to taxes imposed by prior acts as well as those imposed by the 1924 and 1926 Acts. Generally speaking, the Board has no jurisdiction over determinations which do not involve deficiencies. ${ }^{94}$ A deficiency is defined as the difference between the amount shown on the return, if a return was filed, and the amount actually due. In the Appeal of the Continental Accounting and Audit Company, ${ }^{95}$ the taxpayer claimed classification as a personal service corporation. It prepared and filed, however, an ordinary corporation tax return

90 Appeal of Gutterman Strauss Co., supra, n. 26: "They [penalties] are to be assessed and collected in the same manner as a deficiency in tax and inasmuch as an appeal lies in this Board from a determination of a deficiency in tax an appeal will also lie ... with respect to the determination of the correctness of the imposition of the penalty." In the Appeal of Fred Ascher (1925) 2 B. T. A. 1257, the fraud penalty. was asserted by the Board on motion of the Commissioner at the conclnsion of the hearing, although not previously asserted in the deficiency letter.

91 $\$ \$ 274(\mathrm{e}), 283$ (a), 308(e) and 318(a), 1926 Act.

$82 \S \S 280$ and 316,1924 Act.

$93 \S \S 283$ and 318,1926 Act.

94 For example, there is no right of appeal from a determination that the taxpayer is not entitled to tax exempt status unless as a result thereof a deficiency is proposed; Appeal of Permanent Ioan \& Savings Assoc. (1925) 2 B. T. A. 132. Probably the only exception to this rule is in the case of transferees under $\$ \S 280$ and 316 of the 1926 Act. Even in these cases there mnst be a deficiency in so far as the original taxpayer is concerned.

95 (1925) 2 B. T. A. 761. 
showing a tax due. To this return was attached a claim in abatement based on its claim for personal service, and no part of the tax shown to be due was paid. The Commissioner rejected the claim in abatement but did not increase the tax shown due by the return. The Board assumed jurisdiction. ${ }^{96}$

Under the 1924 Act, a taxpayer had in general a right of appeal to the Board regardless of the cause of the deficiency. Even if the deficiency was due to a mathematical error on the face of the return, it was a deficiency within the meaning of section 273 of that act. Under the 1926 Act, however, there is no right of appeal to the Board in the case of a deficiency attributable solely to a mathematical error on the return. ${ }^{97}$ The question of what constitutes a mathematical error is not, however, free from doubt. In such cases the taxpayer may be expected to file an appeal and enjoin collection pending a decision on the point by the Board. A somewhat different phase of the same problem arises in special assessment cases. Under what are generally known as the relief provisions of the 1917, 1918 and $1921 \mathrm{Acts}^{98}$ the Commissioner was authorized in certain cases to determine the profits tax rate of a given taxpayer by comparison with the rate established for other representative taxpayers engaged in the same general line of business. The Commissioner has without exception contended that the determination of whether the taxpayes: was entitled to special assessment, and, if so, the rate applicable, was solely within his discretion and that a deficiency based on either the refusal to allow special assessment or to select proper comparatives was not subject to review by the Board. The Commissioner has consistently refused to produce before the Board the comparatives employed on the ground that it would constitute a violation of the secrecy provisions of the revenue acts. In a leading case $\mathrm{e}^{30}$ the

96 The Board said in part: "The returns should be read as ... includirig the protests (and claim in abatement) ... Rend as a whole the returins show no amount as the tax or show the tax to be zero." A somewhat similar situation arises in the case of tentative returns. In Appeal of Matteawan Mfg. Co. (1926) 4 B. T. A. 956, the tentative return showed a tax liability in excess of that shown by the final return and a claim in abatement of the difference was filed. From the rejection of the claim the taxpayer appealed. The Board held that the final return and not the tentative return was the return contemplated by $\S 273$ of the 1924 and 1926 Acts and denied the Commissioner's motion to dismiss. See also, Appeal of Covert Gear Co., Inc. (1926) 4 B. T. A. 1025.

$97 \S \S 274(\mathrm{f})$ and $308(\mathrm{f}), 1926$ Act.

o\& $\S 210,1917$ Act; $\$ \S 327$ and 328,1918 and 1921 Acts.

ss Appeal of Oesterlein Machine Co. (1924) 1 B. T. A. 159. In this case the Supreme Court of the District of Columbia ordered the Commissioner to produce before the Board the returns of comparative taxpayers. The Comnissioner appealed to the Court of Appeals of the District where the 
Board overruled the Commissioner and assumed jurisdiction. The rule thus laid down has been consistently followed by the Board. Because of the refusal of the Commissioner to produce comparatives, the Board has not attempted to fix the rate applicable. It would seem, however, that if the taxpayer produces evidence of the profits tax rate of proper comparatives, the Board, in absence of any evidence on the part of the Commissioner, should fix the rate on the evidence before it and recompute the tax liability accordingly.

\section{JURISDiction Over YeArs OtHER than those for} WHICH A DEFICIENCY Is Asserted

The rule that there must be a deficiency in every case in order for the Board to assume jurisdiction has always been subject to certain exceptions. The Board is charged with the duty of determining the true deficiency. The tax liability of one year is inextricably related to the invested capital of a preceding year. Even though the preceding year or years are not specifically included in the deficiency letter from which the appeal is taken, the Board may consider all matters in such prior years as are necessary to a determination of the true deficiency for the year before it. ${ }^{100}$ This right is exercised whether or not the other years have been audited by the Commissioner. There is an affirmative grant of this right to consider other years in the 1926 Act, ${ }^{101}$ although it was lacking in the 1924 Act. In certain cases arising under the 1924 Act the Board has gone even further and actually determined the correct tax liability for years for which no deficiency was shown, provided such years were included in the letter covering the year for which a deficiency was asserted..$^{102}$ For example, if a deficiency was asserted for 1920 and an overassessment shown for 1919, and both years were included in the same letter, the Board will assume jurisdiction for the year 1919 for the purpose of determining whether the over-assessment shown should not be increased and set off against the deficiency for 1920. The Board's answer to the Commissioner's contention that the Board is

appeal was argued and the case submitted on October 11, 1926. The decision of the Supreme Court of the District was affirmed by the Court of Appeals January 3, 1927. The Commissioner has not yet announced his determination with respect to this decision. It has been intimated that a review by the United States Supreme Court will be requested.

100 Appeal of Bruin Coal Co. (1924) 1 B. T. A. 83; Appeal of Hickory Spinning Co. (1925) 1 B. T. A. 409.

${ }_{101} \$ 274(\mathrm{~g}), 1926$ Act.

102 Appeal of E. J. Barry (1924) 1 B. T. A. 156; Appeal of Eagle Dye

Works (1925) 1 B. T. A. 638. 
really deciding that the taxpayer is entitled to a refund is that the true deficiency for 1920 can only be determined by a finding as to the amount of the over-payments for previous or subsequent years. Although this rule is subject to question, it may probably be justified in view of the fact that over-payments for any year are to be credited against the deficiency for any other year. ${ }^{103}$ There would logically seem to be no reason why this rule should not be applied even where the year for which an over-payment was claimed by the taxpayer has rot been included in the deficiency letter, or where said year has not been audited by the Commissioner. The Board, however, has refused to assume jurisdiction of such other years where they have not been audited by the Commissioner. ${ }^{104}$

In a recent interesting case, ${ }^{105}$ the Commissioner attempted to invole the foregoing rule to oust the Board of jurisdiction. In this case a deficiency was asserted for 1917. An over-assessment for 1918 exceeding in amount the deficiency for 1917 was shown by the same letter. The Commissioner moved to dismiss the taxpayer's appeal on the ground that the notice was a notice of a net overassessment. The Board denied the Commissioner's motion and assurned jurisdiction. The decision was obviously correct; any other conclusion would enable the Commissioner to deprive the taxpayer of the right of appeal wherever the deficiency could be offset by an over-assessment for another year. In any case where the Board has considered a year where no deficiency has been asserted, its findings for such year are not considered binding on either party. ${ }^{108}$ This seems to be the rule even though the exact amount of an over-assessment for such other year was determined by the Board and set off against the deficiency asserted for another year. The soundness of this rule seems doubtful.

The rule established by the Board under the 1924 Act with regard to the determination of over-assessments for other years has been abandoned by the Board under the 1926 Act. The express provision in the $1926 \mathrm{Act}^{207}$ authorizing the Board to consider other years in determining the deficiency for the year before it, also provides that the Board "shall have no jurisdiction to determine whether or not the tax for any other taxable year has been overpaid or under-

103 § 281, 1924 Act; § 284, 1926 Act.

104 Appeal of Gress Mfg. Co. (1926) 3 B. T. A. 977.

105 Appeal of Minden Lumber Co. (1925) 2 B. T. A. 234.

106 Appeal of Hickory Spinning Co., supra, n. 99; Appeal of Estate of Mary E. Jackman (1925) 2 B. T. A. 515.

$107 \$ 274(\mathrm{~g}), 1926$ Act. 
paid." This provision has been held to supersede the rule laid down in the Appeal of E. J. Barry. ${ }^{108}$. This limitation on the jurisdiction of the Board has been more than offset, however, by the provisions in the new act authorizing the Board to find and order refunds for years properly before it. ${ }^{109}$ Under the 1924 Act, the Board had no authority to determine that a refund was due or that a claim for credit should be allowed. ${ }^{110}$ If a taxpayer elects to appeal to the Board under the 1926 Act from the deficiency proposed, he must press to a conclusion before the Board his claim for overpayment for that year. The statute specifically forbids a taxpayer from later presenting his claim to the Bureau or instituting suit therefor in the courts. ${ }^{111}$ The taxpayer may, however, pay the deficiency proposed and bring suit in court to recover the deficiency paid, together with any other amount to which he may be entitled, without appealing to the Board at all. As a matter of fact, even if the Board finds an overpayment due, the Commissioner may force the taxpayer into court by refusing to make the refund ordered by the Board. The Board is given no authority by the statute to enforce its judgments in this particular. The findings of the Board in such a case, when its decision becomes final, would presumably be binding in all future litigation. The power to order such refunds applies to all cases not heard by the Board before February 26, 1926, regardless of the date the petition was filed.

\section{The Deficiency Asserted May Be Increased by the Board}

Although, as has been pointed out, the Commissioner under the $1926 \mathrm{Act}^{122}$ is precluded, except in case of fraud, from mailing more than one notice of final determination for each taxable period, the Commissioner may assert and the Board may find a greater deficiency than that shown by the deficiency letter. ${ }^{113}$ If the Commissioner proposes to assert a greater deficiency than that shown by the notice appealed from, claim therefore must be made either at or before the hearing. Under the 1924 Act, the Commissioner frequently

${ }^{108}$ Supra, n. 101. See also Appeal of Cornelius Cotton Mills (1926) 4 B. T. A. 255 .

$109 \$ \$ 284(e)$ and $319(c), 1926$ Act.

130 Appeal of Everett Knitting Works, supra, n. 12.

$113 \$ \$ 284(\mathrm{~d})$ and $319(\mathrm{a}), 1926$ Act.

$112 \$ \$ 274(f)$ and 308(f), 1926 Act.

$123 \$ \$ 274(\mathrm{e})$ and 308(e), 1926 Act. The Board had power to increase the deficiency under the 1924 Act although express authority therefor does not appear in the statute. Appeal of The Hotel de France Co. (1924) 1 P. T. A. 28 . 
asserted in his answer to the taxpayer's petition an error in the deficiency letter which if corrected would increase the deficiency. In such cases the Commissioner was required to establish his contention by appropriate evidence and to sustain the burden of proof. It is assumed that such procedure will continue under the 1926 Act as the assertion in question is not the determination of an additional deficiency within the contemplation of the statute.

Under both the 1924 and 1926 Acts, ${ }^{114}$ a jeopardy assessment in a case: pending before the Board might be made in an amount either greater or less than the amount shown in the notice of final determination. In such cases the Board is authorized to redetermine the entire deficiency. The jeopardy assessment, if made after the decision of the Board, may not exceed the amount of the deficiency deternined by the Board. No jeopardy assessment in any amount may be made after the decision of the Board has become final or after the taxpayer has filed a petition for review of the Board's decision. ${ }^{115}$ Under the 1924 Act the Board has increased the deficiency in proper cases even though claim therefor was not made by the Commissioner and despite the absence of express warrant for such action in the statute. Express authority therefor is contained in the 1926 Act.

\section{JURISDICTION IN CASE OF BANKRUPTCY OR RECEIVERSHIP}

In certain special cases, even though a deficiency may have been asserted by the Commissioner, the Board may have no jurisdiction. In cases of bankruptcy or receivership, the Commissioner is required by the 1926 Act $^{116}$ to assess immediately the deficiency proposed. This assessment, while in a strict sense a jeopardy assessment, is not governed by the ordinary rules applicable to such assessments, ${ }^{117}$ and the Commissioner is not required to issue to the taxpayer within sixty days from the date of the assessment the usual deficiency letter. As a inatter of fact, if a petition has not been filed with the Board at the time of the receivership or bankruptcy, the taxpayer is specifi-

$114 \S \S 279$ (c) and 312, 1926 Act. In such cases, the Commissioner may, in effect, by forcing the taxpayer to give a bond, nnllify the provisions forbidding more than one determination. It is assumed in such cases, however, that the burden of proof with regard to the excess assessed will devolve on the Connmissioner. There was no express authority in the 1924 Act for a jeopardy assessment in an amount greater than that shown in the deficiency letter, but such authority was assumed by the Commissioner.

115 \$ $\$ 279$ (e) and $312(\mathrm{e}), 1926$ Act.

116 . 282,1926 Act.

$117 \$ 279$ and 312, 1926 Act. 
cally precluded ${ }^{118}$ from filing such a petition despite the fact that a sixty-day letter may be outstanding. Even though the receivership or bankruptcy occurs after the appeal is filed, a claim for the tax assessed may be filed by the Collector at the instance of the Commissioner with the court in which the bankruptcy or receivership proceedings are pending. ${ }^{119}$ If such a claim is filed, it would appear that the Board loses jurisdiction of the appeal. If the Commissioner elects not to file a claim in court, it would seem that the Board may proceed with its determination.

\section{EfFect of Payment of the Tax on the JURISDICTION OF THE BOARD}

Under both the 1924 and 1926 Acts, jurisdiction of the Board may depend on whether or not the deficiency proposed has been paid. This may be expected in view of the fact that in general the Board is called upon to decide whether or not a proposed deficiency should be paid. Under the 1924 Act, the Board would not assume jurisdiction in any case where the tax had been paid prior to the filing of the appeal. To do so would involve the determination of whether or not the taxpayer was entitled to a refund, which the Board has consistently and properly refused to undertake. ${ }^{120}$ Under the 1924 Act, the same rule prevailed in case the taxpayer paid the tax while an appeal was pending and even though payment was made as the result of a jeopardy assessment and to avoid interest. ${ }^{121}$ The Board's rule in these cases is based on the proposition that after payment the subject-matter of the litigation is no longer in controversy. While the rule is probably correct, its application may result, and has resulted under the 1924 Act, in hardship to the taxpayer. For example, if a jeopardy assessment were made while an appeal was pending and the taxpayer were unable to furnish bond, the Board is ousted of jurisdiction. ${ }^{122}$ This is true even though payment is not made. If a bond can not be furnished and the tax is collected by distraint, the Board loses jurisdiction. The anomalous situation of

118 Supra, n. 116.

119 Supra, n. 116.

120 Appeal of Everett Knitting Works, supra, n. 12. 767.

121 Appeal of The Northwestern Mutual Life Ins. Co. (1925) 1 B. T. A.

122 Appeal of Cal. Assoc. Raisin Co., supra, n. 43. Under the 1926 Act, the giving of a bond is not a prerequisite to jurisdiction. If no bond is given, however, the collector is required to collect the tax and the final result is the same as that under the 1924 Act. 
one party to a litigation ousting the tribunal of jurisdiction without the consent of either the tribunal or the opposing party is the result.

A clifferent rule with regard to payment prevails under the 1926 Act although it is not entirely clear from the statute what effect payment was intended to have on the jurisdiction of the Board. ${ }^{128}$ Under the new act, the taxpayer is specifically authorized at any time to waive the restrictions on assessment or collection in effect after the issuance of the deficiency letter and during the pendency of the appeal. ${ }^{124}$ It might be inferred that even after payment an appeal might be filed within the sixty-day period and that payment after the appeal was filed would not oust the Board of jurisdiction. If this construction is not adopted, the provisions of the statute pernitting payment at any time become meaningless as the taxpayer has always had the right by voluntarily dismissing his appeal to pay the deficiency proposed.

It would seem that a similar rule should prevail with regard to jeopardy assessments made after the passage of the 1926 Act. The Commissioner is required under the 1926 Act to issue a deficiency letter to the taxpayer within sixty days from the date of the assessment. ${ }^{225}$ If no bond to stay collection is given, the tax must be paid. The obligation to issue the sixty-day letter, however, is not dependent on whether or not payment is made. It would appear, therefore, that an appeal may be filed after a jeopardy assessment even though the tax has been paid. The same condition would prevail if the jeopardy assessment were made while the appeal is pending. If this were not so, then in those cases where the taxpayer could not furnisi a bond the Commissioner could enforce collection without a hearing on the merits and with no right on the part of the taxpayer to sue in court to recover the amount thus collected. ${ }^{126}$ This result would be even more onerous than the effect of payment under the 1924 Act, which the 1926 Act was intended to remove. It would appear that any payment after February 25, 1926, regardless of the year involved or the nature of the assessment, should not deprive

$123 \S \S 274$ (d) and 308(d), 1926 Act.

124 Contained in $\$ \S 274(\mathrm{a})$ and 308(a), 1926 Act.

$125 \$ \$ 279(\mathrm{~b})$ and $312(\mathrm{~b}), 1926$ Act.

126 Sections 284 and 319 of the 1926 Act give the Board jurisdiction to determine overpayments, and with certain exceptions, prohibit any refund to a taxpayer who has filed a petition after February 25, 1926, except through the Board. In other words, a taxpayer who once files a petition with the Board has elected his tribunal and must abide by its decision or that of the proper appellate body. For an excellent discussion of the effect of payment on the jurisdiction of the Board, see Hamel, United States Board of Tax Appeals-Practice and Evidence, p. 78, n. 7. 
the Board of jurisdiction provided only that the final determination occurred after the above date.

The question of payment in certain cases is specifically mentioned in the 1924 Act in defining the jurisdiction of the Board. These cases are chiefly those concerning which doubt existed under the 1924 Act as to the jurisdiction of the Board. In all cases where the determination occurred after February 25, 1926, but the tax was assessed prior thereto, the Board has jurisdiction, provided the tax was not paid in full prior to February 26, 1926.127 In cases where the final determination occurred before February 26, 1926, but after June 2,1924, the Board has jurisdiction regardless of the date of assessment, provided the tax was not paid in full before June 3, 1924. ${ }^{128}$ In those cases where the deficiency letters were mailed within sixty days of February 26,1926, but petitions had not been filed on that date, the Board has jurisdiction, provided payment in full was not made prior to February 26, 1926.129 It would appear from these statutory provisions that the Board was intended by Congress to have jurisdiction in all cases where the tax had not been paid on the effective date of the act under which the final determination was made.

\section{Jurisdiction of the Board in Spectal Cases}

Although the Board is a tribunal of limited jurisdiction, it has jurisdiction to decide all the issues involved in a case properly before it. The Board has jurisdiction under both the 1924 and 1926 Acts to determine whether or not the deficiency proposed by the Commissioner is barred by the statute of limitations, ${ }^{130}$ and all subsidiary questions in connection therewith may be determined at the same time. The Board also has the power, specifically granted for the first time by the $1926 \mathrm{Act}^{131}$ to impose a fine or penalty upon a taxpayer for a frivolous appeal. This provision was inserted to discourage the filing of appeals merely for the purpose of postponing the date of payment of a tax admittedly due. The penalty, if imposed by the Board, is assessed and collected as a part of the deficiency in $\operatorname{tax}$.

$127 \S \$ 283(\mathrm{a})$, (e) and $318(\mathrm{a}),(\mathrm{d}), 1926$ Act.

$128 \$ \$ 283$ (b), (f) and 318(b), (e), 1926 Act.

$129 \$ 283$ (c), (g) and 318(c), (f), 1926 Act. 236.

130 Appeal of The National Refining Co. of Ohio, et al. (1924) 1 B. T. A.

$131 \S 911,1926$ Act. 


\section{BoARd Without JURISDiction Unless APPEAL Is Filed Within Sixty-Day Period}

While the deficiency letter ${ }^{132}$ usually states on its face that sixty days are allowed within which to file an appeal, a notice may be issued. which may be in fact a final determination but not so state on its face. In any event, under both the 1924 and 1926 Acts the appeal must be filed with the Board within sixty days from the date said notice of final determination was mailed to the taxpayer. If the notice is mailed under the 1926 Act, Sunday is excluded if the sixtieth day. ${ }^{133}$ Under the 1924 Act, no provision was made for exclucling Sunday if the sixtieth day. ${ }^{134}$ The Board has strictly construed this jurisdictional requirement. The petition must be filed within the required period with some person authorized and designated by the Board to receive it or jurisdiction will not be assumed..$^{135}$ Depositing the appeal in the mails addressed to the Board is not sufficient. The period begins to run at midnight of the date of mailing and it is immaterial what date is stamped or printed on the face of the deficiency letter. Nor is the Commissioner estopped from asserting that the sixty-day period has expired because of the fact that the deficiency letter bore no date or because it was mailed on a date other than the one it bears. ${ }^{136}$ The taxpayer is bound to determine at his peril the date the letter was mailed and file the: appeal accordingly. The date stamped on the notice and the date cf mailing will, in practically all cases, be the same, as the stamping of the date on the notice immediately precedes the mailing. The erract date of mailing can always be ascertained in case of doubt by reference to the Commissioner's registry record, as the statute requires that all such notices be sent by registered mail. ${ }^{137}$

A recent interesting decision of the Board emphasizes the necessity for specifying in the petition with certainty the date of the notice appealed from. In the appeal of Eastman Gardiner Naval Stores Company ${ }^{138}$ a so-called thirty-day letter covering the year 1919 was mailed to the taxpayer on August 26, 1925. It is well settled that no appeal to the Board lies from such a notice as it is not the Commissioner's final determination. On November 19, 1925, the customary

182 .Designated the NP 2 letter.

$133 \$ 274$ and 308,1926 Act.

$134 \$ 274$ and 308,1924 Act.

135 Appeal of Sam Satovsky, supra, n. 73.

136 Appeal of Hurst, Anthony \& Watkins (1924) 1 B. T. A. 26.

137 274(a) and 308(a), 1924 and 1926 Acts.

138 (1926) 4 B. T. A. 242. 
notice of final determination covering the same year was mailed to the taxpayer. Apparently these notices were identical as to adjustments and additional tax proposed. Thereafter, within sixty days of November 19, 1925, but more than sixty days after August 26, 1925, the taxpayer filed an appeal with the Board. The appeal, however, was stated to be from the letter of August 26, 1925. The Commissioner moved to dismiss and the motion came on for hearing more than sixty days after November 19, 1925. At the hearing the taxpayer moved to amend the petition by changing the date of the letter appealed from as set forth in the petition from August 26, 1925, to November 19, 1925. The taxpayer's motion was denied on the ground that more than sixty days had elapsed since November 19, 1925, and the Commissioner's motion to dismiss was allowed.

The correctness of this decision appears to be subject to serious question. According to this decision, if any date other than the date on which the letter was mailed is set forth in the petition, the Board has no jurisdiction unless a motion to amend and insert the correct date is made within sixty days of the true date of mailing. This ruling may become important in a number of cases. The thirty-day letter might be dated September 1 and the sixty-day letter November 1 and both be identical in substance and the petition state that the letter appealed from was mailed October 1 . Or, the appeal might by mistake purport to be from a letter mailed October 1 whereas it was actually mailed, as shown on its face, October 2 or September 30. In no one of the above cases will the Board assume jurisdiction, regardless of when the petition was filed. Of course, if the letter stated to be appealed from is different in substance from the true deficiency letter, the Board's decision would clearly be correct. But where the taxpayer intended to appeal from the true letter and filed his appeal within sixty days from the date of mailing, but through a typographical error stated the date of said deficiency notice erroneously, the Board's rule would seem to be unnecessarily harsh. The taxpayer by statute is given the right to appeal from a notice of deficiency rather than a specified date.

Subject to the limitations already specified, the jurisdiction of the Board under the 1926 Act, depending on the year involved and the date of assessment, may be summarized as follows:

1. Determinations under the 1926 Act ${ }^{139}$ of Taxes Imposed by That Act:

139 Under this head are included the years from 1925 on. The final determination in all such cases, except where the taxpayer was on a fiscal year basis, must occur after February 26, 1926, the date of the passage of the 
(a) Where no assessment, either jeopardy or otherwise, has been made, the Board clearly has jurisdiction; ${ }^{140}$

(b) Where a jeopardy assessment is made after February 26, 1926, the Board has jurisdiction ;141

(c) It is intended by the provisions of the 1926 Act that no ordinary assessment will be made after February 26, 1926, except after the allowance of an appeal to the Board and the decision of the Eioard has become final. The assessment or collection of the $\operatorname{tax}$ in such a case without the allowance of an appeal may be enjoined..$^{142}$

2. Determinations of Deficiencies in Taxes Imposed by Prior Acts. ${ }^{3.43}$

(a) If no determination and no assessment has been made prior to February 26, 1926, the Board has jurisdiction; ;44

(b) If assessed before June 3, 1924, but no determination was made until after February 26, 1926, the Board has jurisdiction regardless of the nature of the assessment, provided only that the tax was not paid in full before February 26,$1926 ;^{145}$

(c) If assessed after June 2, 1924, but before Februaty 26, 1926, and the determination occurs after February 26, 1926, the Board has jurisdiction;

(aa) If the assessment was a jeopardy assessment, the provisions of the $1924 \mathrm{Act}^{146}$ are retained for such special cases in the 1926 Act; ;47

(bb) No ordinary assessment after June 2, 1924, except after an appeal to the Board and a final decision thereon was contemplated in the 1924 Act. There was no specific provision for enjoining such assessments, however, in the 1924 Act. If a case should arise where such an assessment had been made, the

1926 A.ct, as the returns for the calendar year 1925 were not due until March $15,1925$.

The outline here presented is equally applicable to income, profits, estate and gift taxes. Gift taxes, however, were imposed only for 1924 and 1925 under the 1924 Act and are to be assessed, collected and paid in the same manner as estate taxes. Estate tax statutes govern generally only from date of enactment. Appropriate sections of the statutes covering estate taxes will be cited with those sections covering income and profits taxes.

$140 \$ \$ 274(\mathrm{a})$ and $308(\mathrm{a}), 1926$ Act.

$141 \$ 279$ and 312,1926 Act.

$142 \S \$ 274(\mathrm{a})$ and $308(\mathrm{a}), 1926$ Act.

143 Includes all Acts from 1916 through 1924 and years 1916 through 1924.

$144 \S \S 283$ (a) and $318(\mathrm{a}), 1926$ Act.

$145 \$ 283(\mathrm{e})$ and $318(\mathrm{~d}), 1926$ Act.

$148 \S \$ 279$ and 312,1924 Act.

$147 \S \S 283(\mathrm{k})$ and $318(\mathrm{i}), 1926$ Act. 
Commissioner is still required to issue a sixty-day letter giving the right of appeal when the final determination actually occurs;

(cc) In all such cases it is essential that there be no payment of the tax before February 26, 1926.

3. Final Determinations of Taxes Imposed by Prior Acts Made Prior to February 26, 1926, and the Appeal is Filed, Pending and: Undecided on That Date.

(a) If no assessment has been made prior to June 3, 1924, and the final determination occurred after June 2, 1924, but before February 26,1926 , the Board has jurisdiction ${ }^{148}$ regardless of the year involved; $; 19$

(b) If assessed before June 3, 1924, but final determination occurred after June 2, 1924, but before February 26, 1926, the Board has jurisdiction regardless of the nature of the assessment, provided the tax was not paid in full before June 3,$1924 ; \mathbf{1 5 0}$

(c) If assessed because of jeopardy after June 2, 1924, but before February 26, 1926, and the final determination occurred after June 2, 1924, but before February 26, 1926, the Board has jurisdiction, provided the tax was not paid in full before February 26, $1926 ; \mathbf{1 5 1}$

(d) It was the intention of Congress that no final determination should be made after June 2, 1924, until after the appeal to the Board and the Board's decision had become final. There was no provision for a claim in abatement under the 1924 Act except in jeopardy assessinents. If such an assessment was made after June 2 , 1924, and the final determination occurred before February 26, 1926, and an appeal was filed, the Board would have jurisdiction.

4. Cases in Which Final Determinations of Deficiencies in Taxes Imposed by Prior Acts Occurred Prior to February 26, 1926, but Within Sixty Days of That Date and no Appeal Had Been Filed with the Board on February 26, I926. ${ }^{162}$

(a) If the tax was not assessed, the Board has jurisdiction; ${ }^{153}$

(b) If assessed before June 3, 1924, the Board has jurisdiction

$148 \S \S 274,280,308$ and 316, 1924 Act.

$149 \$ 283(\mathrm{~b})$ and $318(\mathrm{~b}), 1926$ Act.

$150 \S \S 283(\mathrm{f})$ and $318(\mathrm{e}), 1926$ Act.

$151 \$ 279$ and 312,1924 Act; $\$ \$ 283(\mathrm{k})$ and $318(\mathrm{i}), 1926$ Act.

152 Under this heading are included bnt relatively few cases where the determinations were made after June 2,1924 , but notices were not mailed before Dec. 27, 1925, and no appeal had been filed with the Board before Feb. 26, 1926. In such cases, the taxpayer was allowed sixty days from Feb. 26 , 1926, within which to file the appeal, or through April 27, 1926.

$153 \S \S 283$ (c) and $318(\mathrm{c}), 1926$ Act. 
regardless of the nature of the assessment, provided the tax was not paid in full before February 26, 1926;154

(c) If a jeopardy assessment was made after June 2, 1924, the Board has jurisdiction; ;155

(d) It is contemplated by the 1924 Act that no ordinary assessment would be made after June 2, 1924, except after an appeal to the Board. If such a case should arise under the circumstances here specified, the Board would have jurisdiction.

San Francisco, California.

Dana Latham. 